\title{
On Revisiting the Sex Differences in Language Acquisition: An Etiological Perspective
}

\author{
Nima Shakouri ${ }^{1}$, Parviz Maftoon ${ }^{1} \&$ Parviz Birjandi $^{1}$ \\ ${ }^{1}$ Department of English, Science and Research Branch, Islamic Azad University, Tehran, Iran \\ Correspondence: Parviz Maftoon, College of Foreign Languages and Literature, Science and Research Branch, \\ Islamic Azad University, Tehran, Iran. E-mail: pmaftoon@gmail.com
}

Received: March 12, 2016

Accepted: June 20, 2016 Online Published: July 13, 2016

doi:10.5539/ijel.v6n4p87

URL: http://dx.doi.org/10.5539/ijel.v6n4p87

\begin{abstract}
The purpose of the study is to investigate the issue of sexual brains in language acquisition from an etiological perspective. In a sense, the etiological scrutiny of sexual brain will enhance our understanding of brain functioning in order to avoid the totally abstract assumptions pioneered by numerous scholars in second language acquisition (SLA). To achieve the aforementioned aim, the current work taking a conservative approach holds that male-female interactional differences are primarily nature-based in language acquisition, for "individuals are initially affected by biology, before societal constructs can have any influence on them" (Lewin, 2003, p. 3).
\end{abstract}

Keywords: etiology, hippocampus, sexual dimorphism, SLA, symmetrical brain

\section{Introduction}

There seems to be no end to the debate over sex differences in the brain. The fact that males and females have different brains is not being surprising, but the implication is quite important because it means that not all brains think the same way (Haier \& Jung, 2008). This simple fact might inspire and fix the notion of individualism in language acquisition. That is, sexual brain investigation calls on a necessity to evaluate each student as an individual. Having agreed that there exist individual differences in female and male brain structures, the present researchers, then, will face an even more intense debate over what these differences mean.

However, Hartshorne \& Ullman (2006) argue until now, sex has been virtually ignored in studies of learning languages. Still, one of the ways in which the study of sex differences can make a difference is to investigate what changes and matters in brain systems make female and male language acquisition distinct. Females, for instance, because of the high level of estrogen, are better at using declarative memory (Hartshorne \& Ullman, 2006). Accordingly, Haist, Shimamura, \& Squire (1992) put forth that the high amount of estrogen in females contributes to recalling facts and knowledge.

In effect, the study of sex differences provides a unique opportunity to elucidate the entire trajectory from genes to behavior. Meanwhile, the scrutiny of the sexual brain will enhance our understanding of brain functioning in order to avoid the totally abstract assumptions pioneered by numerous scholars. Hartshorne \& Ullman (2006) also assert "the consistent introduction of sex as a design factor in language acquisition may help to reduce the heterogeneity of findings across studies which might have varied in previous investigations partly as a result of inconsistent sex ratios among subjects" (p. 30).

That males and females have a unique ability to learn more than one language is actually a well-established fact. Nevertheless, understanding the sexual brain differences central to language acquisition may present the single most important challenge to the next decade, especially if it turns out that the sexual basis of the brain is amenable to educational strategies, for instance. Whether this can be true is an empirical question yet to be answered, and there is a relatively little investigation of this issue given its critical importance. As Haier \& Jung (2008) put forth:

although research in cognitive psychology has advanced considerably in the last two decades, it is still not known why some people learn faster than others, or why some people have better memories or longer attention spans than other people, or why some people are much better at mathematical reasoning than at spelling, or why some people are more creative than others. (p. 171) 
It is not yet clear whether the sex differences between females and males are more or less biologically socio-cultural or socio-culturally biological, but what is clear is the fact that these two, that is, sociocultural and biological perspectives towards sexual nature of the brain, are highly interdependent. Undeniably, language acquisition is socio-culturally bound; that is, some concepts are more acceptable in some cultures than others for men and women. There is so much research being conducted in this field, but what is felt a deficit in research is to see whether the brain function in females and males has an advantage for them to acquire language or not. Although several scholars (e.g., Wallentin, 2009) do not believe in sex as a confounding factor in language proficiency, the present writers are in attempts to provide a valid understanding that the sexual brain distinction between females and males can have important implications in the realm of language acquisition, in general, and SLA, in particular.

\section{Review of the Related Literature}

\subsection{Need for a Biological Perspective}

Prior to 1980 s, very little philosophical work drew seriously on scientific work including the nervous system (Brook \& Akins, 2005). In the 20th century, the idea of mind and brain was conceptualized; that is, "a purely physical thing such as the brain could give rise to the complex patterns of feeling and thought" (Warburton, 2013, p. 139). However, the notion of actual brain science was still paid less heed to. In fact, the philosophy was speculative (Bem \& de Jong, 2006) rather than scientific. Later on, scholars attempted to cross the border between philosophy and psychology. That is, using psychological concepts, philosophers of neuroscience endeavored to investigate the cognitive part of the brain. Nonetheless, some philosophers argue for the elimination of psychological concepts conceived vague and confused.

In sum, the philosophers of neuroscience fall into either the reductionist or the eliminativist camps (Brook \& Akins, 2005). According to reductionists, each psychological state will ultimately be reduced to a type of neurophysiological state. Eliminativists, in contrast, contend that there is no way to reduce psychological theories to neural theories. According to eliminativism, "psychological theories are riddled with errors and psychological concepts are so weak when it comes to building a science out of them that psychological states are best regarded as talking about nothing that actually exists" (Brook \& Akins, 2005, p. 6).

Not challenging the philosophical assumptions of the given perspectives, the present researchers are keen on investigating the brain differences from biological/etiological perspectives. Most of the studies conducted in the realm of language acquisition were mostly assumption-based rather than biology-based. The naturalistic theory, for instance, is based on the assumption (Altenaichinger, 2003) that language acquisition is innately determined and that we are born with a certain system of language that we can call on later (Chomsky, 2000). Krashen's (1981) input hypothesis, also, merits from an assumption (Altenaichinger, 2003) that holds it is important for the acquirer to understand the language that is a bit beyond his or her current level of competence.

Research on the neurobiology of language shows that female brains exhibit certain structural differences related to the biological differences between sexes and that these differences may indeed correlate with differences in cognition and language acquisition (Shehadeh, 1999). Meanwhile, no one denies that there are sexual brain differences between females and males. Accordingly, Zaidi (2010) maintains that since male and female brains are wired differently, they learn differently. Moir \& Jessel (1989), also, report that girls tend to use areas of the brain devoted to verbal and emotional functioning, while boys generally use the areas of the brain geared toward spatial and mechanical tasks.

In other words, the studies on sex differences in the human brain are inspired by the idea that individuals consist of brains which are essentially male/female (Karafyllis \& Ulshöfer, 2008). Generally speaking, as Baron-Cohen (2004) contends, the female brain, for instance, "spontaneously empathizes to a greater degree than do males" (p. 248), while the male brain is adept at systemizing. "Systemizing is the drive to derive the underlying rules that govern the behavior of a system" (p. 248). However, little has been investigated from an etiological perspective. That is, why are males adept at systemizing? And in much the same way, why are females good at empathizing?.

In sum, outlining the socio-cultural differences between females' and males' way of communication does not pave the way towards elucidating the etiology of one sex superiority in language acquisition over the other. Henceforth, to shape the structure of the paper, the researchers, in line with Celce-Murcia (2001), take a more conservative stance and hold that male-female interactional differences, in particular, have sex-based as well as socio-cultural origins in language acquisition. Thus, the current work, besides regarding that language acquisition is more or less socio-culturally bound, insists on the sex-based origin of language acquisition. Along the same line, the researchers of the present paper following Holmes \& Meyerhoff (2007) hold that there would be a risk if researchers ignore the bilateral communication of biology and sociology in interpreting the influence 
of sex on language acquisition. Accordingly, Halpern \& Tan (2001) argue that "biology and environment are as inseparable as conjoined twins who share a common heart" (p. 395).

Tannen, (1990) on claiming that language acquisition is biologically bound holds that the way men talk to men is very different from the way women talk to women. These differences in communication style and communication strategy may result in different strengths and weaknesses in terms of language learning that might correlate with the sexual brain. Although the way of talking is culturally bound (Holmes \& Meyerhoff, 2007), it will be a risk to disregard the role of biological sex in language acquisition.

In fact, it can be claimed that even women's sensitivity to new linguistic forms has a biological basis. Ellis (1994) holds that women, because of sensitivity to new forms, are more inclined to incorporate the standardness of speech. Men, in contrast, use a higher frequency of nonstandard forms than women, and, in the majority of linguistic changes, women use a higher frequency of the incoming forms than men do. What causes a bone of contention is whether this sensitivity is because of sexual brain structure or not. Although the given issue has been discussed more or less from the socio-cultural perspective, there is little research conducted in this field from an etiological perspective. That is, why do females have an advantage in language abilities? (Eriksson et al., 2012). Are there any biological reasons? Do females biologically tackle L2 learning differently from males? Do sex differences entail a nature or nurture explanatory scenario or both?

Studies conducted by Ullamn (2005) and Kimura (1999) hold that the differences between male and female brain cognitive functioning are partly because of hormonal configurations. Seen from this stance, "there is indeed a processing difference between males and females and that this processing exists in both $\mathrm{L} 1$ and at least in highly practiced L2" (Bowden, Sanz, \& Stafford, 2005, p. 114). As to Halpern (2002), females show an advantage over men at verbal memory tasks, while males are inclined towards visuospatial tasks (Kimura, 1999). Research shows that language processing differences between males and females are related to the verbal memory and the influence of estrogen upon it (Sanz, 2005). Moreover, the production of male sex hormone is also critical in this respect (van der Slik, van Hout, \& Schepens, 2015). In effect, masculinization of behavior in males causes a variety of differences between males and females in motor skills and visuospatial abilities (Willingham \& Cole, 1997).

Studies also show that the level of estrogen, for instance, plays a significant role in the sea-saw effect (Kimura, 1999; Ullman, 2004) "such that a dysfunction of one system results in enhanced learning in the other or that learning in one system depresses the functionality of the other" (Ullman, 2005, p. 147).

\subsection{Sexual Brain Differences}

\subsubsection{Brain Gray and White Matter}

Generally speaking, there are two types of matter in the brain - gray and white (Magon, 2009). Gray matter comprises dendritic structures associated with processing power, while white matter is made from myelinated fibers (insulated electrical wire) that act as connections between gray matter structures (like network cables). In this regard, gray matter represents information processing centers in the brain, and white matter represents the connections between these processing centers. The abovementioned findings can help us to explain why men tend to excel in tasks requiring more local processing like mathematics, while women tend to excel at integrating and assimilating information from distributed gray-matter regions in the brain.

The proportion of gray to white matter between males and females differs significantly in different regions of the brain (Allen, Damasio, Grabowski, Bruss, \& Zhang, 2003). Research shows that male brains contain approximately 6.5 times more gray matter related to intellectual processing than female brains, and female brains contain 10 times more white matter linked with intelligence than males do (Haier \& Jung, 2008; Ho, Roessmann, Straumfjord, \& Monroe, 1980). Along the same line, identifying regional differences with brain reports that $84 \%$ of gray-matter regions and $88 \%$ of white-matter regions involved with intellectual performance in women are found in the brain's frontal lobes, compared to $45 \%$ and $0 \%$ percent for males. In other words, the gray matter driving male intellectual performance is distributed throughout more of the brain.

Research (e.g., Celce-Murcia, 2001; Ellis, 1994) also shows that females are faster and easier to process and communicate. Magon (2009) sees the reason in the intensity of gray matter rather than the amount of gray matter. Put differently, in females' brain gray matter, made up of active neurons, "is packed in tightly, so that they are closer together" (Zaidi, 2010, p. 37). The relationship that exists between gray matter density and language proficiency may represent a general principle of brain organization (Mechelli et al., 2004). To conclude, owning to the density of gray matters in the female brain, they are better processors and communicators (Roost, 2012). 


\subsubsection{Symmetrical Brains}

The notion of symmetrical brains in females is also a heated debate. In effect, the two areas in the frontal and temporal lobes related to language named as Broca \& Wernicke, respectively were significantly larger in women (Schlaepfer, Harris, Tien, Peng, \& Pearlson, 1995). Researchers (e.g., Haier \& Jung, 2008) assert that males tend to think with their gray matter, whereas females with their white matter that provides connections between the neurons. What contributes to the symmetries in females' brain is not the approximation but the density of gray matter and the proportion of white matter that allow a female brain to work faster and account for the sexual differences in how males and females think and behave (Sabbatini, 2000). Schlaepfer et al. (1995) using magnetic resonance imaging, measured the gray matter in 17 females and 43 males. They reported that "women had 23.2\% (in Broca's area, in the dorsolateral prefrontal cortex) and 12.8\% (in Wernicke's area, in the superior temporal cortex) greater gray matter percentages... than men in a language-related cortical region" (p. 129). Along the same vein, Harasty, Double, Halliday, \& McRitchie (1997) argue for the anatomical differences in the Wernicke \& Broca areas among males and females. Their findings showed that the volume of the Wernicke's area was $18 \%$ larger in females compared with that volume in males, and the cortical volume of the Broca's area in females was $20 \%$ larger than in that of males.

Males and females are also different in multiple tasks. Rua (2006) asserts that "although both males and females have the same linguistic potentials as human beings, females' linguistic skills somehow seem more prone to be stimulated in order to reach higher levels of linguistic competence" (p.103). This persuasively leads us to Moir \& Jessel's (1989) claim that "brains of males and females are constructed differently, resulting in important differences in perceptions, emotional expression, priorities and behavior" (p. 5).

Zuckerman (2005), also, asserts that the differences between the male and female brain will undeniably have an impact on their communication. Zuckerman goes on to hold that the two sides of the brain (i.e., hemispheres), in men, operate more independently. In women, in contrast, the left and the right hemispheres of the brain are in nonstop communication; this might explain why women are better able to recover language skills after suffering a left brain stroke and why they tend to have better language skills (Glass, 1992). In this regard, based on the issue of lateralization, a number of studies have suggested that language is more left-lateralized in males than females; that is, males depend particularly on the left-hemisphere of the brain for language, whereas in females the brain bases of language are more bilaterally distributed (Ullman, Miranda, \& Traver, 2008). Put differently, women brain process language simultaneously in the two hemispheres, whereas men just process the language on the left side (Shaywitz et al., 1995).

Research done on females with unilateral lesions also lends support to the claim that females are in fact more bilateralized with their verbal abilities (Frith \& Vargha-Khadem, 2001). In fact, when a female has experienced a lesion to the left hemisphere, she is better able to compensate for this damage than a male is. If a male has a lesion in the left hemisphere, his verbal abilities are greatly impaired in comparison to a male of the same age without that damage (Frith \& Vargha-Khadem, 2001). However, to Magon (2009), it is not correct to say that men are more left-brained (logical, objective) and women more right-brained (creative, emotional). In fact, both sexes use both hemispheres of the brains regularly. Still, human male brains are more asymmetrically lateralized than those of females, and this brain asymmetry explains why females are "configured for multi-tasking performance" (Pease, 2001).

As Sommer, Aleman, Bouma, \& Kahn (2004) report, the theory that sex differences arise from the more bilateral representation of language functions in females than in males is supported by two findings. First, female stroke patients have been reported to exhibit verbal impairment less frequently after lesions of the left hemisphere than male patients. Secondly, structural MRI studies demonstrated that asymmetry of the planum temporale (the upper surface of the temporal lobe largely overlapping with Wernicke's area) is less pronounced in females than in males.

Another reason concerning symmetries in the female brain is that the amount of white matter in corpus callosum is more in females than in males (Padmini \& Rao, 2011). Magon (2009) maintains that corpus callosum hemispheric bridge has commonly been associated with the ease of bilateral brain processing. It is generally thought that there is gender-related thickness difference in this white matter structure among males and females. In sum, this thickness is more in females. Henceforth, Gurian \& Stevens (2004) hold that greater callosum thickness would allow for better "cross talk between hemispheres in the female brain" (p. 22).

Difference in the size of corpus callosum also lends support to sexual dimorphism; that is, the two sexes of a species differ in external appearance or other features. Males and females may differ in size, color, shape, production (Jefferson, 1990) and even in language acquisition. As stated by Bornstein, Hahn, \& Haynes (2004), 
sexual dimorphism in the lateralization of language has been stronger in females, giving them the greater left hemisphere dominance on language acquisition. One identified sexual dimorphism with potential implications for language is the sizes of some portions of the corpus callosum, a difference that has been related to verbal fluency. Accordingly, this can be a biological strong indicator of women's ability in building communication.

The growth of corpus callosum and hippocampus is in line with the experience the individuals achieve from the environment. Chiang et al. (2009) hold "synaptic connectivity, dendritic complexity, and myelination vary dynamically throughout life, responding to sensory stimulation or deprivation, nutritional factors, and rearing environment" (p. 2212). Accordingly, Chiang et al state that, an important step in finding out "the determinants of white matter integrity is to find quantifiable measures of white matter integrity in the brain that are related to cognition" (p. 2212). Chiang et al. state that as compared with the gray and white matter, corpus callosum reveals greater evidence for environmental influence. In the same vein, Maguire et al. (2000) state that expert taxi drivers had larger posterior hippocampal, and this is a reflection of the experience-based plasticity of structure involved spatial navigation. The authors provided a correlation between years of experience and hippocampal volume. Schneider et al. (2002) also report greater gray matter volume in auditory cortex for musicians. They also supported their findings with the years of experience and higher gray matter.

\subsubsection{Sex Hereditary Impact on Language Acquisition}

A body of evidence suggests that sex also has a hereditary impact on language acquisition. The proponents of the innateness hypothesis (e.g., Chomsky, 2000) point out that human languages share certain universal properties that even in the absence of negative evidence children acquire language very quickly and relatively with fewer errors. Nevertheless, they rarely refer to whether these properties have distinct advantages for the two sexes.

One of the newer theories concerning language acquisition states that sex differences in a mother's use of Infant-Directed Speech (IDS) towards her infant cause the differences in language acquisition (Bergeson \& Trehub, 1999). Bergeson \& Trehub continue that IDS features aspects of speech including shorter utterances, longer pauses, a slower speech rate, higher pitch, and hyper-articulated vowels, all of which have been proven to facilitate language acquisition. In 2003, Kitamura \& Burnham published a study to demonstrate that mothers use IDS more towards females than they do towards males. They determined that mothers use IDS both to encourage attention and express affection more with female infants and suggested that this difference arises because of the mother's intuitive adaptation of speech to her child's perceived developmental needs. In the same line, Ladegaard \& Bleses's (2003) frequency hypothesis supports the claim that males and females hear different features because of how they are viewed by their caregivers. The study by Echols \& Newport (1992) indicated that children are probably to produce and recognize the syllables stressed in their caregivers' speech.

\section{Implications of Sex Differences in SLA}

Being aware of the extent to which sex influences language acquisition provides some insights which help the L2 teachers to teach more effectively. In other words, the biological fact that males and females have different brains, and so they use different pathways for the same tasks have implications about how to approach different sexes, their learning styles and the work they produce in the language classroom. Julé (2004, cited in Uster, 2008) puts forth "anatomy is not destiny, as Freud suggested, but a learner's sex or, more likely, gender- can have profound effects on the ways that learners approach language learning, ways which may, in turn, affect proficiency" (p. 19).

Study on the brain will also pave the way towards how to approach language teaching. As Uster (2008) maintains, the structures of male and female brains indicate the ways about their learning patterns, memory, and retention. In fact, taking into accounts the different biology of the sexual brains results in serious pedagogical implications. According to Uster, teachers, for instance, do not have to "keep verbal instructions too long since males might lose attention since their brain is not oriented for long speech" (p. 160). Furthermore, the teachers "must allow physical movement and physical activity for boys who mostly are physically oriented" (p. 160).

In addition, the course books cannot be sex-blind. The material developers should also consider sex while selecting the topics. Interesting topics provide a stimulus. If the topics trigger stimulation in the brain of the learner, according to Sylwester (1995), the stimulation can change into nervous impulse. The impulse will be sent to thalamus which leads to a map formation in the hippocampus. Then there will be a signal distribution to different parts of the brain. After receiving the input, the signal of dendrite growth is sent. When the cell body transmits a message to the axon, the stored chemical moves into the synaptic gap. The released chemical triggers the nearby dendrites. Henceforth, the produced energy moves to the other cell bodies which finally ends up with more dendrites branching. The more dendrites branching, the more potential for learning will be available. Therefore, avoiding repetitive topics and considering males taste in material development can trigger them to 
cope with the course more comfortably.

Research also shows that females outperform male in social skills. To put some examples, Uster (2008), maintains that in order to develop males' social skills, teachers must increase employment of group work and pair work to help boys socialize. There are also some implications to take into account in the classroom when the characteristics of the female brain are considered. For example, teachers must support their instruction with objects to avoid too many abstractions which are favored by the male brain. To help the female brain, there must be some visual elements such as charts and written material.

\section{Conclusion}

To better appreciate the etiological implications of sex in language acquisition, recall that male and female brains biologically do have the same floor plan, but not all brains work the same way. The density, amount, and the activation of certain brain region appear to underlie the superiority of one sex over the other. Although numerous studies have been reported on the differences between girls and boys on their manner of production, what the paper considers a challenge is to stop elaborating on their differences based on assumptions. Not proposing new assumptions in the realm of language acquisition, the current paper goes on to hold that since the dendritic cells in males' gray matters are more in comparison with females', males are expected to have a strong connection with the outside environment; however, what research shows is that this superiority on the part of females is more or less because of the density of gray matter that facilitates the act of connecting and processing.

In sum, female brains process language activities more easily, earlier, and faster than males, while males more readily excel at spatial-mechanical and gross motor skill tasks. Gurian \& Stevens (2004) conclude that these differences explain why girls outperform boys in reading and writing, and why boys tend to gravitate towards physical activities. Furthermore, because of the high amount of white matter in corpus callosum which acts as a bridge between two hemispheres, the female brains benefit from bilateralization. Henceforth, they are good at communication.

It seems investigating sex difference debate from an etiological perspective opens new horizon towards SLA. However, evidence from brain research is not something new. More importantly, studying the brain and finding the differences that exist between male and female brains can push us towards offering a remedy for the lag which is felt behind in male and female language achievement.

\section{References}

Allen, J. S., Damasio, H., Grabowski, T. J., Bruss, J., \& Zhang, W. (2003). Sexual dimorphism and asymmetries in the gray-white composition of the human cerebrum. NeuroImage, 18, 880-894. http://dx.doi.org/10.1016/S1053-8119(03)00034-X

Altenaichinger, A. (2003). Theories of second language acquisition. In M. Hanak-Hammerl \& D. Newby (Eds.), Second language acquisition: The interface between theory and practice (pp. 7-31). Graz: Graz University.

Baron-Cohen, S. (2002). The extreme male brain theory of autism. TRENDS in Cognitive Sciences, 6(6), 248-254. http://dx.doi.org/10.1016/S1364-6613(02)01904-6

Bem, S. B., \& de Jong, H. L. (2006). Theoretical issues in psychology: An introduction. London: Sage Publications.

Bergeson, T. R., \& Trehub, S. E. (1999). Mothers' singing to infants and preschool children. Behavior and Development, 22, 51-64. http://dx.doi.org/10.1016/S0163-6383(99)80005-8

Bornstein, M. H., Hahn, C. H., \& Haynes, O. M. (2004). Specific and general language performance across early childhood: Stability and gender considerations. First Language, 24, 267-304. http://dx.doi.org/10.1177/0142723704045681

Bowden, H. W., Sanz, C., \& Stafford, C. (2005). Individual differences: Age, sex, working memory, and prior knowledge. In C. Sanz (Ed.), Mind and context in adult second language acquisition (pp. 105-140). Washington, DC: Georgetown University Press.

Brook, A., \& Akins, K. (2005). Cognition and the Brain: The philosophy and neuroscience movement. In A. Brook \& K. Akins (Eds.), Cognition and the brain: The philosophy and neuroscience movement (pp. 1-26). Cambridge: Cambridge University Press. http://dx.doi.org/10.1017/CBO9780511610608

Celce-Murcia, M. (2001). Teaching English as a second or foreign language. London: Cengage Learning Ltd.

Chiang, M. C., Barysheva, M., Shattuck, D. W., Lee. A. D., Madsen, S. K., Avedissian, C., ... Thompson, P. M. (2009). Genetics of brain fiber architecture and intellectual performance. The Journal of Neuroscience, 


\section{9(7), 2212-2224. http://dx.doi.org/10.1523/JNEUROSCI.4184-08.2009}

Chomsky, N. (2000). The minimalist inquiries. In R. Martin, D. Michaels, \& J. Uriagereka (Eds.), Essays on minimalist syntax in honor of Howard Lasnik (pp. 89-155). Cambridge: MIT Press.

Echols, C., \& Newport, E. (1992). The role of stress and position in determining first words. Language acquisition, 2, 189-220. http://dx.doi.org/10.1207/s15327817la0203_1

Ellis, R. (1994). The study of second language acquisition. Oxford: Oxford University Press.

Eriksson, M., Marschik, P. B., Tulviste, T., Almgren, M., Perez Pereira, M., Wehberg, S., \& Gallego, C. (2012). Differences between girls and boys in emerging language skills: Evidence from 10 language communities.

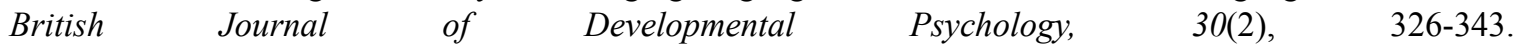
http://dx.doi.org/10.1111/j.2044-835X.2011.02042.x

Frith, U., \& Vargha-Khadem, F. (2001). Are there sex differences in the brain basis of literacy related skills? Evidence from reading and spelling impairments after early unilateral brain damage. Neuropsychologia, 39, 1485-1488. http://dx.doi.org/10.1016/S0028-3932(01)00063-X

Glass, L. (1992). He says, she says: Closing the communication gap between the sexes. New York: G.P. Putnam's Sons.

Gurian, M., \& Stevens, K. (2004). With boys and girls in mind. Educational Leadership, 62(3), 21-26.

Haier, R. J., \& Jung, R. E. (2008). Brain imaging studies of intelligence and creativity: What is the picture for education. Roeper Review, 30, 171-180. http://dx.doi.org/10.1080/02783190802199347

Haist, F., Shimamura, A. P., \& Squire, L. R. (1992). On the relationship between recall and recognition memory. Journal of Experimental Psychology: Learning Memory and Cognition, 18(4), 691-702. http://dx.doi.org/10.1037/0278-7393.18.4.691

Halpern, D. F. (2002). Sex differences in cognitive abilities (3rd ed.). Mahwah, NJ: Lawrence Erlbaum.

Halpern, D. F., \& Tan, U. (2001). Stereotypes and steroids: Using a psychobiosocial model to understand cognitive sex differences. Brain and Cognition, 45, 392-414. http://dx.doi.org/10.1006/brcg.2001.1287

Harasty, J., Double, K. L., Halliday, G. M., Kril, J. J., \& McRitchie, D. A. (1997). Language-associated cortical regions are proportionally larger in the female brain. Arch Neurol, 54, 171-176. http://dx.doi.org/10.1001/archneur.1997.00550140045011

Hartshorne, J. K., \& Ullman, M. T. (2006). Why girls say "holded" more than boys. Developmental Science, 9(1), 21-32. http://dx.doi.org/10.1111/j.1467-7687.2005.00459.x

Ho, K. C., Roessmann, U., Straumfjord, J. V., \& Monroe, G. (1980). Analysis of brain weight II. Adult brain weight in relation to body height, weight, and surface area. Arch Pathol Lab Med, 104(12), 640-645.

Holmes, J., \& Meyerhoff, M. (2007). Different voices, different views: An introduction to current research in language and gender. In J. Holmes \& M. Meyerhoff (Eds.), The handbook of language and gender (pp. 1-12). London: Blackwell Publishing.

Jefferson, T. A. (1990). Sexual dimorphism and development of external features in Dall's porpoise. Phocoenoides dalli, 88, 119-132.

Jule, A. (2004). Gender, participation and silence in the language classroom: Sh-Shushing the girls. New York: Palgrave Macmillan. http://dx.doi.org/10.1057/9780230596627

Karafyllis, N. C., \& Ulshöfer, G. (2008). Introduction: Intelligent emotions and sexualized brains—discourses, scientific models, and their interdependencies. In N. C. Karafyllis \& G. Ulshöfer (Eds.), Sexualized brains: Scientific modeling of emotional intelligence from a cultural perspective (pp. 1-49). Cambridge: MIT Press.

Kimura, D. (1999). Sex and cognition. Cambridge: The MIT Press.

Kitamura, C., \& Burnham, D. (2003). Pitch and communicative intent in mother's speech: Adjustments for age and sex in the first year. Infancy, 4, 85-110. http://dx.doi.org/10.1207/S15327078IN0401_5

Krashen, S. D. (1981). Second language acquisition and second language learning. Oxford: Pergamon.

Ladegaard, H., \& Bleses, D. (2003). Gender differences in young children's speech: The acquisition of sociolinguistic competence. International Journal of Applied Linguistics, 13, 222-233. http://dx.doi.org/10.1111/1473-4192.00045

Lewin, C. (2003). Sex differences in memory and other cognitive abilities (Unpublished doctoral dissertation). 
Stockholm University, Stockholm.

Magon, A. J. (2009). Gender, the brain and education: Do boys and girls learn differently? (Unpublished master's thesis). Amsterdam University, Amsterdam. Retrieved from http://dspace.library.uvic.ca:8080/bitstream

Maguire, E. A., Gadian, D. G., Johnsrude, I. S., Good, C. D., Ashburner, J., Frackowiak, S. J., \& Firth, C. (2000). Navigation-related structural change in the hippocampi of taxi drivers. PNAS, 97(8), 4389-4403. http://dx.doi.org/10.1073/pnas.070039597

Mechelli, A., Crinion, J. T., Noppeney, U., O’Doherty, J., Ashburner, J., Frackowiak, R. S., \& Price, C. J. (2004). Structural plasticity in the bilingual brain. Retrieved from http://faculty.washington.edu/losterho/mechelli_12_vmb.pdf

Moir, A., \& Jessel, D. (1989). Brain sex: The real difference between men and women. New York: Dell Publishing.

Padmini, M. P., \& Rao, N. (2011). Sexual dimorphism of corpus callosum occurs in human fetuses. People's Journal of Scientific Research, 5(1), 15-18.

Pease, A. (2001). Why men can't listen and women can't read maps. London: Harper Collins Ltd.

Roost, A. (2012). Exploring brain differences: Male vs female. Retrieved from http://www.hormonesmatter.com/brain-differences-male-female/

Rua, P. L. (2006). The sex variable in foreign language learning: An integrative approach. Porta Linguarum, 6, 99-114.

Sabbatini, R. M. E. (2000). Are there differences between the brains of males and females? Retrieved from http://www.cerebromente.org.br/n11/mente/eisntein/cerebro-homens.html

Schlaepfer, T. E., Harris, G. J., Tien, A. Y., Peng, L., Lee, S., \& Pearlson, G. D. (1995). Structural differences in the cerebral cortex of healthy female and male subjects: a magnetic resonance imaging study. Psychiatry Res., 61(3), 129-135. http://dx.doi.org/10.1016/0925-4927(95)02634-A

Schneider, P., Scherg, M., Dosch, H. G., Specht, H. J., Gutschalk, A., \& Rupp, A. (2002). Morphology of Heschl's gyrus reflects enhanced activation in the auditory cortex of musicians. Nature Neuroscience, 5(7), 688-964.

Shaywitz, B. A., Shaywitz, S. A., Pugh, K. R., Constable, R. T., Skudlarski, P., Fulbright, R. K., ... Gore, J. C. (1995). Sex differences in the functional organization of the brain for language. Nature, 373(16), 607-609. http://dx.doi.org/10.1038/373607a0

Shehadeh, A. (1999). Gender differences and equal opportunities in the ESL classroom. ELT Journal, 53(4), 256-261. http://dx.doi.org/10.1093/elt/53.4.256

Sommer, I. E. C., Aleman, A., Bouma, A., \& Kahn, R. S. (2004). Do women really have more bilateral language representation than men? A meta-analysis of functional imaging studies. Brain, 127(8), 1845-1852. http://dx.doi.org/10.1093/brain/awh207

Sylwester, R. (1995). A celebration of neurons. Virginia: Association for Supervision and Curriculum Development.

Tannen, D. (1990). You just don't understand: Women and men in conversation. Cambridge: Cambridge University Press.

Ullman, M. T. (2005). A cognitive neuroscience perspective on second language acquisition: The declarative/ procedural model. In C. Sanz (Ed.), Mind and context in adult second language acquisition (pp. 141-178). Washington, DC: Georgetown University Press.

Ullman, M. T., Miranda, R. A., \& Travers, M. L. (2008). Sex differences in the neurocognition of language. In J. B. Becker, K. J. Berkley, N. Geary, E. Hampson, J. P. Herman, \& E. A. Young (Eds.), Sex differences in the brain from genes to behavior (pp. 291-309). Oxford: Oxford University Press.

Uster, S. (2008). The role of brain-based gender differences on the vocabulary learning and consolidation skills and strategies (Unpublished master's thesis). Retrieved from etd.lib. metu.edu.tr/upload/12610252/index

van der Slik, F. W. P., van Hout, R. W. N. M., \& Schepens, J. J. (2015). The gender gap in second language acquisition: Gender differences in the acquisition of Dutch among immigrants from 88 Countries with 49 mother tongues. PLOS ONE, 10(11). http://dx.doi.org/10.1371/journal.pone.0142056 
Wallentin, M. (2009). Putative sex differences in verbal abilities and language cortex: A critical review. Brain and Language, 108, 175-183. http://dx.doi.org/10.1016/j.bandl.2008.07.001

Warburton, N. (2013). Philosophy: The basics. New York: Routledge.

Willingham, W. W., \& Cole, N. S. (1997). Gender and fair assessment. Mahwah, NJ: Erlbaum.

Zaidi, Z. F. (2010). Gender differences in human brain: A review. The Open Anatomy Journal, 2, 37-55. http://dx.doi.org/10.2174/1877609401002010037

Zuckerman, C. S. (2005). The perception of gender differences in communication and the link to the nature or nurture theory (Unpublished master's thesis). Retrieved from http://domapp01.shu.edu/depts/uc/apps/library repository.nsf/resource

\section{Copyrights}

Copyright for this article is retained by the author(s), with first publication rights granted to the journal.

This is an open-access article distributed under the terms and conditions of the Creative Commons Attribution license (http://creativecommons.org/licenses/by/3.0/). 